\title{
ANALISIS PENGARUH RASIO LIKUIDITAS DAN RASIO PROFITABILITAS TERHADAP PENILAIAN KONDISI KEUANGANPERUSAHAAN PADA PT MANDOM INDONESIA TBK
}

\author{
Leersia Hexsandra ${ }^{1}$, Rina Dameria ${ }^{2}$ \\ Sekolah Tinggi Ilmu Ekonomi Jayakarta \\ Jakarta, Indonesia \\ leersiahaw48@gmail.com, rinanapitupulu_dew@yahoo.com
}

\begin{abstract}
Abstrak
Penelitian ini bertujuan untuk menganalis kondisi keuangan dengan menggunakan rasio likuiditas dan rasio profitabilitas sebagai alat ukur. Populasi dalam penelitian ini merupakan laporan keuangan PT Mandom Indonesia Tbk, yang terdaftar di Bursa Efek Indonesia tahun 2011-2018. Pengambilan sampel dengan menggunakan Purposive Sampling. Sampel dalam penelitian ini adalah 8 sampel pada laporan keuangan PT Mandom Indonesia Tbk yang terdaftar di Bursa Efek Indonesia (BEI) pada tahun 2011-2018. Teknik analisis data menggunakan analisis regresi linear berganda. Hasil penelitian ini menunjukkan bahwa secara parsial rasio likuiditas dan rasio profitabilitas memiliki pengaruh yang signifikan (positif) terhadap kondisi keuangan. Nilai adjusted R-Square atau besarnya koefisien determinasi sebesar 0.962. Hal ini menyatakan bahwa besarnya kontribusi dari rasio likuiditas dan rasio profitabilitas sebagai alat dalam menilai kondisi keuangan sebesar 96.2 $\%$, yang dapat disimpulkan kedua rasio ini memiliki pengaruh yang sangat besar dalam menentukan kondisi keuangan. Sedangkan sisanya sebesar $3.8 \%$ dipengaruhi oleh faktor (variabel) lain di luar model regresi dalam penelitian ini yang tidak diteliti.
\end{abstract}

Kata Kunci : Perputaran Modal Kerja, Rasio Likuiditas, dan Laba Bersih

\section{PENDAHULUAN}

Dunia bisnis dewasa ini berkembang semakin cepat, karenanya dituntut pengelolaan perusahaan yang lebih baik. Keuangan merupakan salah satu masalah yang sangat vital bagi perusahaan dalam menentukan perkembangan bisnisnya. Untuk dapat berkembang dengan baik, manajemen dalam suatu perusahaan perlu mengetahui dengan pasti beberapa faktor penunjang seperti salah satunya ialah kondisi keuangan dalam perusahaan itu sendiri. . Kondisi keuangan dapat diketahui dengan melakukan perumusan pada laporan keuangan perusahaan. Suatu laporan keuangan harus menjadi informasi yang jelas kerena sangat penting dalam menilai kondisi dalam suatu perusahaan.

Oleh karena itu, laporan keuangan dapat digunakan sebagai alat untuk berkomunikasi dengan pihak-pihak yang berkepentingan dengan menggunakan data keuangan perusahaan. 
Analisis laporan keuangan menggunakan perhitungan rasio-rasio keuangan agar dapat mengevaluasi keadaan finansial perusahaan dimasa lalu, sekarang, dan masa yang akan datang. Di samping itu, rasio juga dibuat berdasarkan tujuan dari pihak penganalisa dalam mengevaluasi kinerja suatu perusahaan berdasarkan laporan keuangannya. Secara garis besar, dalam melakukan analisis laporan keuangan diperlukan suatu metode dan teknik analisis yang tepat.

Kreditur jangka pendek lebih menekankan untuk menilai kemampuan perusahaan untuk membayar utang-utang yang segera harus dilunasi. Sementara itu, kreditur jangka panjang lebih menekankan untuk menilai kemampuan perusahaan dalam membayar bunga pinjaman dan kemampuan membayar pokok pinjaman, jadi di samping likuiditas maka tingkat profitabilitas (profitability) juga dinilai.

Di lain sisi, para pemegang saham selain menilai likuiditas dan profitabilitas, juga memerhatikan tingkat pengembalian (return) terhadap investasi yang ditanamnya. . Lain lagi dengan calon investor yang lebih melihat pada rasio penilaiannya (valuation) untuk menentukan layak atau tidaknya saham perusahaan tersebut untuk dimiliki. Maka dari itu penting bagi pihak manajemen untuk memahami kondisi keuangannya sendiri.

\section{LITERATUR DAN METODE}

\section{Penilaian Kondisi Keuangan}

Laporan keuangan merupakan sebuah informasi yang merangkum seluruh kegiatan (aktivitas) perusahaan. Salah satu tugas penting bagi manajemen perusahaan adalah melakukan penyusunan laporan keuangan setiap tahun. Laporan keuangan menggambarkan kondisi keuangan dan hasil usaha suatu perusahaan pada saat tertentu atau jangka waktu tertentu.

Bagi para analis, laporan keuangan merupakan media yang paling penting untuk menilai prestasi dan kondisi ekonomis suatu perusahaan. Laporan keuangan dapat menggambarkan posisi keuangan perusahaan, hasil usaha perusahaan dalam suatu periode, dan arus dana (kas) perusahaan dalam periode tertentu.

Dalam literatur akuntansi neraca atau laporan posisi keuangan berasal dari istilah "balance sheet", "statement of financial position", "statement of financial conditions" atau "statement of recources and liabilities". Laporan ini menggambarkan posisi aktiva, kewajiban, dan modal pada saat tertentu. Jadi neraca adalah suatu laporan yang sistematis tentang aktiva (assets), kewajiban (liabilities), dan modal sendiri (equity) dari suatu perusahaan pada tanggal atau waktu tertentu. 
FASB Statement (Sofyan Safri Harahap, 2016: 113), memberikan definisi revenue sebagai arus kas masuk atau peningkatan nilai asset dari suatu entity atau penyelesaian kewajiban dari entity atau gabungan keduanya selama periode tertentu yang berasal dari penyerahan atau produksi barang, pemberian jasa atas pelaksana kegiatan lainnya yang merupakan kegiatan perusahaan yang sedang berjalan.

Dalam FASB Statement No. 95 (Sofyan Safri Harahap, 2016: 118), muncul lagi cash flow statement atau laporan arus kas yang masih harus diterapkan pada pelaporan tahun buku 1989. Dalam laporan ini, transaksi kas dikelompokan pada tiga bagian yaitu:

a. Transaksi kas yang berasal dari kegiatan operasi.

b. Transaksi kas yang berasal dari kegiatan pembiayaan.

c. Transaksi kas yang berasal dari kegiatan investasi.

\section{Rasio Likuiditas}

Menurut Lyn M.Fraser (Arief Sugiono dan Edi Untung, 2016: 56), rasio likuiditas (solvensi jangka pendek), yang mengukur kemampuan perusahaan untuk memenuhui kebutuhan uang tunai. Terdiri dari rasio lancar (current ratio), rasio cepat (quick ratio), dan rasio aliran kas (cash flow liquidity ratio).
1) Current Ratio

Rasio ini digunakan untuk mengetahui sejauh mana aktiva lancar perusahaan digunakan untuk melunasi utang (kewajiban) lancar yang akan jatuh tempo atau segera dibayar. Current ratio biasa digunakan untuk mengukur solvensi jangka pendek.

Cash Ratio $=\frac{\text { Kas }}{\text { Utang Lancar }}$

2) Quick Ratio (Acid Test Ratio)

Pos persediaan tidak dihitung dalam rasio ini, kerena persediaan merupakan pos yang paling tidak likuid dalam aktiva lancar mengingat panjangnya tahap yang dilalui untuk menjadi kas.

$$
\text { Quick Ratio }=\frac{\text { Aktiva Lancar }- \text { Persediaan }}{\text { Utang lancar }}
$$

3) Cash Ratio

Rasio ini merupakan perbandingan antara kas yang ada di perusahaan (cash on hand) dan di bank (termasuk surat berharga seperti deposito) dibandingkan dengan total utang lancar. Rasio ini menunjukkan kemampuan kas perusahaan untuk melunasi hutang lancarnya tanpa harus mengubah aktiva lancar bukan kas (piutang dagang dan persediaan) menjadi kas.

$$
\text { Cash Ratio }=\frac{\text { Kas }}{\text { Utang Lancar }}
$$




\section{Rasio Profitabilitas}

Rasio ini bertujuan untuk mengukur efektivitas manajemen yang tercermin pada imbalan atas hasil investasi melalui kegitan perusahaan atau dengan kata lain mengukur kinerja perusahaan secara keseluruhan dan efisiensi dalam pengelolaan kewajiban dan modal.

1) Gross Profit Margin

Rasio ini menunjukkan berapa besar keuntungan kotor yang diperoleh dari menjual produk.Selain margin laba kotor ada baiknya jika kita juga menghitung persentase dari laba usaha, yaitu:

$$
\text { Gross Profit Margin }=\frac{\text { Laba Kotor }}{\text { Penjualan }}
$$

Untuk kondisi normal, laba kotor seharusnya positif karena menunjukkan perusahaan menjual barang di atas harga pokoknya.

2) Net Profit Margin atau Return on Sales (ROS)

Rasio ini menunjukkan berapa besar keuntungan bersih yang diperoleh perusahaan. Jika profit margin suatu perusahaan lebih rendah dari rata-rata industrinya, maka hal ini dapat disebabkan oleh harga jual perusahaan lebih rendah daripada perusahaan pesaing atau harga pokok penjualan lebih tinggi dari perusahaan pesaing, ataupun kedua-duanya.

$$
\text { Net Profit Margin }=\frac{\text { Laba Bersih }}{\text { Penjualan Bersih }}
$$

3) Cash Flow Margin

Cash Flow Margin adalah persentase aliran kas dari hasil operasi terhadap penjualannya. Cash flow margin mengukur kemampuan perusahaan untuk merubah penjualan menjadi aliran kas.

$$
\text { Cash Flow Margin }=\frac{\text { Arus kas hasil operasi }}{\text { Penjualan Bersih }}
$$

4) Return on Asset (ROA)

Rasio ini mengukur tingkat pengembalian dari bisnis atas seluruh asset yang ada. Atau rasio ini menggambarkan efisiensi pada dana yang digunakan dalam perusahaan. Oleh karena itu, sering pula rasio ini disebut return on investment (ROI).

$$
\text { ROA/ROI }=\frac{\text { Laba Bersih }}{\text { Total Aktiva }}
$$

\section{5) Return Of Equity}

Rasio ini mengukur tingkat pengembalian dari bisnis atas seluruh modal yang ada. ROE merupakan salah satu indikator yang digunakan pemegang saham untuk mengukur keberhasilan bisnis yang dijalani.

$$
\text { ROE }=\frac{\text { Laba Bersih }}{\text { Total Ekuitas }}
$$




\section{METODE PENELITIAN}

\section{Populasi dan Sampel}

Secara generalisasi, populasi adalah keseluruhan objek penelitian yang berfungsi sebagai sumber data dalam penelitian. Berdasarkan pengertian populasi tersebut, maka yang dijadikan populasi dalam penelitian ini adalah Laporan Keuangan PT Mandom Indonesia Tbk 2015-2018. Pada penelitian ini sumber data dikumpulkan dengan menggunakan teknik purposive sampling. Berikut beberapa kriteria yang harus dipenuhi untuk pemilihan sampel dalam penelitian ini adalah sebagai berikut:

a. Perusahaan yang masih aktif dan tercatat dalam Bursa Efek Indonesia (BEI).

b. Laporan keuangan enam tahun terakhir dari tahun penelitian dimulai.

c. Laporan keuangan yang telah selesai diaudit dan diberikan opini oleh auditor.

\section{Metode Pengumpulan Data}

Data yang digunakan dalam penelitian ini adalah data sekunder. Untuk mengumpulkan data yang diperlukan dalam penulisan skripsi ini, harus menggunakan teknik penulisan pengumpulan data, yaitu pengamatan langsung dan dokumentasi, yaitu dengan mencatat dan memfotokopi dokumen yang berhubungan dengan penelitian yang dilakukan.

\section{Analisis Regresi Berganda}

Dalam penelitian ini menggunakan analisis regresi berganda, karena variabel bebas yang digunakan dalam penelitian ini lebih dari satu. Sugiyono (2017: 270) mengemukakan: “...Analisis regresi berganda didasarkan pada hubungan fungsional ataupun kausal variabel independen dengan variabel dependen." Menurut Sugiyono (2017: 270), persamaan rumus regresi linear berganda dalam penelitian ini adalah:

$$
\mathrm{Y}=\mathrm{a}+\mathrm{b}_{1} \mathrm{X}_{1}+\mathrm{b}_{2} \mathrm{X}_{2}
$$

Keterangan:

$\mathrm{Y}=$ Nilai skor Laba Bersih

$\mathrm{a}=$ Konstanta

$b_{1}, b_{2}=$ Koefisien regresi

$\mathrm{X}_{1}=$ Perputaran Modal Kerja

$\mathrm{X}_{2}=$ Rasio Lancar

\section{HASIL DAN PEMBAHASAN}

\section{Uji Statistik Deskriptif}

Statistik deskriptif dalam penelitian pada dasarnya merupakan proses transformasi data penelitian dalam bentuk tabulasi sehingga mudah dipahami dan diinterpretasikan. Berikut tabel 4.13 merupakan uji analisis statistik deskriptif untuk variabel yang digunakan dalam penelitian ini: 
Tabel 1.1

Descriptive Statistics

\begin{tabular}{|l|r|r|r|r|r|}
\hline & $\mathrm{N}$ & Minimum & Maximum & \multicolumn{1}{c|}{ Mean } & Std. Deviation \\
\hline Rasio Likuiditas & 8 & .38 & 3.59 & 2.1238 & 1.36997 \\
\hline Rasio Profitabilitas & 8 & .13 & .30 & .1825 & .06018 \\
\hline Kondisi Keuangan & 8 & 3.00 & 7.00 & 5.5000 & 1.85164 \\
\hline ValidN (listvise) & 8 & & & & \\
\hline
\end{tabular}

Sumber : Output SPSS 20

1. Rasio Likuiditas memiliki nilai minimum 0.38 dan nilai maksimum 3.59 dengan nilai rata-rata 2.1238 Standar deviasi adalah sebesar 1.36997, jumlah data yang digunakan adalah sebanyak 8 .

2. Rasio Profitabilitas memiliki nilai minimum 0.13 , dan nilai maksimum 0.30 dengan nilai rata-rata 0.1825 . Standar deviasi adalah sebesar 0.06018, jumlah data yang digunakan adalah sebanyak 8 .

3. Kondisi Keuangan memiliki nilai minimum 3.00 dan nilai maksimum 7.00 dengan nilai rata-rata 5.5000, Standar deviasi adalah sebesar 1.85164, jumlah data yang digunakan adalah sebanyak 8 .

\section{Uji Hipotesis}

Berdasarkan nilai adjusted $\mathrm{R}^{2}$ yang diperoleh adalah sebesar 0.962. Hal ini menunjukkan bahwa Kondisi Keuangan pada PT Mandom Indonesia Tbk 20152018 dapat dijelaskan oleh variabel bebasnya yaitu rasio likuiditas dan rasio profitabilitas sebesar $96.2 \%$ dan sisanya
$3.8 \%$ ditentukan oleh variabel lain yang tidak dianalisis dalam penelitian ini.

Tabel 2.1

\begin{tabular}{|l|r|r|r|c|}
\hline \multicolumn{5}{|c|}{ Model Summary } \\
\hline Model & \multicolumn{1}{|c|}{$\mathrm{R}$} & $\mathrm{R}$ Square & $\begin{array}{c}\text { Adjusted R } \\
\text { Square }\end{array}$ & $\begin{array}{c}\text { Std. Error of the } \\
\text { Estimate }\end{array}$ \\
\hline 1 & $.981^{\mathrm{a}}$ & .962 & .947 & .42585 \\
\hline \multicolumn{3}{|l|}{ a. Predictors: (Constant), Rasio Profitabilitas, Rasio Likuiditas } \\
b. Dependent Variable: Kondisi Keuangan \\
\hline
\end{tabular}

Sumber : Output SPSS 20

Berdasarkan hasil uji F diperoleh nilai $F_{\text {hitung }}$ sebesar 63.692 lebih besar dari $F_{\text {tabel }}$ sebesar 5.79 dan nilai probabilitas atau signifikansi $0,000<0,05$. Maka dapat disimpulkan bahwa kedua variabel bebas (rasio likuiditas dan rasio profitabilitas) secara simultan berpengaruh terhadap variabel terikat kondisi keuangan.

Berdasarkan penelitian, diketahui variabel rasio likuiditas memiliki pengaruh terhadap kondisi keuangan, dengan nilai signifikansi sebesar $0,000<0,05$. Hasil pengujian diatas menunjukkan bahwa semakin kecil rasio likuiditas perusahaan maka semakin besar kondisi keuangan untuk mengevaluasi efisiensi dan efektivitas perushaan dalam menghasilkan laba dan posisi kas tertentu.

Apabila tingkat likuiditas baik, perusahaan akan efektif dalam menghasilkan laba dan hal tersebut akan meyakinkan para investor agar percaya untuk berinvestasi pada perusahaan. Yaitu perusahaan dapat memanfaatkan aktiva lancarnya sebaik mungkin untuk 
memenuhi kebutuhan perusahaan sehingga tidak banyak dana yang menganggur.

Berdasarkan penelitian, diketahui variabel rasio profitabilitas tidak memiliki pengaruh $(0.679>0.05)$ terhadap manajemen laba bersih. Hal tersebut menunjukkan bahwa semakin besar rasio profitabilitas perusahaan tidak dapat meningkatkan kondisi keuangan pada perusahaan. Semakin tinggi nilai rasio maka kondisi perusahaan semakin baik berdasarkan rasio profitabilitas. Nilai yang tinggi melambangkan tingkat laba dan efisiensi perusahaan tinggi yang bisa dilihat dari tingkat pendapatan dan arus kas. Investor ataupun kreditur dapat menggunakan rasio-rasio profitabilitas ini untuk menilai laba atas investasi berdasarkan tingkat penggunaan aset dan sumber daya lainnya. Net profit margin dan return on asset berpengaruh secara parsial terhadap laba, sedangkan gross profit margin, cash flow margin, ROA dan ROE tidak berpengaruh secara parsial terhadap laba. Dapat dikatakan laba adalah salah satu akun (pos) yang berpengaruh signifikan terhadap kondisi keuangan perusahaan.

\section{KESIMPULAN}

Berdasarkan pada hasil analisis regresi linier berganda dengan melakukan uji asumsi klasik dan uji hipotesis maka dapat dibuat kesimpulan sebagai berikut:
1. Kondisi keuangan PT Mandom Indonesia Tbk pada tahun 2011 s.d. 2018 dikategorikan stabil. Hal ini dibuktikan dari hasil penelitian berdasarkan tabel pencarian skor kondisi keuangan setelah dirataratakan mendapat skor 5.5 yang masuk dalam kategori stabil.

2. Rasio Likuiditas berpengaruh terhadap kondisi keuangan PT Mandom Indonesia Tbk. Hal ini dibuktikan dari hasil penelitian:

a. Nilai t hitung > t tabel atau 11.035 $>1.94318$, dengan demikian terdapat pengaruh rasio likuiditas terhadap kondisi keuangan.

b. Nilai signifikansi $<0.05$ atau $0.000<0.05$, dengan demikian terdapat pengaruh rasio likuiditas terhadap kondisi keuangan.

c. Nilai korelasi $=0.980$ berarti hubungan rasio likuiditas dengan kondisi keuangan dikategorikan sangat kuat.

3. Rasio Profitabilitas tidak berpengaruh secara signifikan terhadap kondisi keuangan PT Mandom Indonesia Tbk. Hal ini dibuktikan dari hasil penelitian:

a. Nilai t hitung < t tabel atau $0.440<$ 1.94318, dengan demikian tidak terdapat pengaruh yang signifikan antara rasio profitabilitas terhadap kondisi keuangan. 
b. Nilai signifikan $>0.05$ atau $0.679>$ 0.05 , dengan demikian tidak terdapat pengaruh yang signifikan antara rasio profitabilitas terhadap kondisi keuangan.

c. Nilai korelasi $=-0.205$ berarti hubungan rasio profitabilitas dengan kondisi keuangan dikategorikan lemah.

4. Rasio Likuditas dan Rasio Profitabilitas berpengaruh secara simultan terhadap kondisi keuangan PT Mandom Indonesia Tbk. Hal ini dapat dibuktikan dari hasil penelitian:

a. Nilai F hitung > F tabel atau 63.672 $>$ 5.79, dengan demikian dapat disimpulkan bahwa kedua variabel bebas (rasio likuiditas dan rasio profitabilitas) secara simultan berpengaruh terhadap variabel terikat kondisi keuangan.

b. Nilai signifikansi $<0.05$ atau $0.000<$ 0.05 dengan demikian terdapat pengaruh rasio likuiditas dan rasio profitabilitas terhadap kondisi keuangan.

c. Nilai korelasi simultan sebesar 0.981 yang menunjukkan terdapat korelasi yang sangat kuat karena berada di interval $(0.800-1.000)$.

d. Nilai koefisien determinasi menghasilkan nilai atau $\mathrm{R}$ Square = 0.962. Dengan demikian besarnya kontribusi rasio likuiditas dan rasio profitabilitas terhadap kondisi keuangan adalah sebanyak $96.2 \%$ sedangkan sisanya $3.8 \%$ dipengaruhi oleh faktor lain, yang tidak diteliti.

\section{REFERENSI}

Atika, Darminto, dan Siti Ragil Handayani. 2012. "Pengaruh Beberapa Rasio Keuangan terhadap Prediksi Kondisi Financial Distress.” Jurnal Penelitian Ilmu Administrasi.

Darmadi, Hamid. 2013. Dimensi-dimensi Metode Penelitian Pendidikan dan Sosial. Cetakan 1. Bandung: Alfabeta.

Ghozali, Imam. 2006. Aplikasi Analisis Multivariate dengan Program SPSS. Cetakaan Keempat. Semarang: Badan Penerbit Universitas Diponegoro.

Gozali, Imam. 2011. Aplikasi Analisis Multivariate dengan Program IBM SPSS. Semarang: Badan Penerbit Universitas Diponegoro.

Harahap, Sofyan Safri. 2016. Analisis Kritis Laporan Keuangan. Edisi 1 Cetakan 13. Jakarta: Rajawali Pers.

Hery. 2014. Analisis Kinerja Manajemen. Jakarta: Grasindo.

Junia Wati Ningrum. 2015. "Pengaruh Rasio Likuiditas dan Rasio Aktivitas terhadap Pertumbuhan Laba pada PT Kedaung Indah Can Tbk Periode 20102014.” Jurnal Ilmiah Prodi Akuntansi. 
Kariyoto. 2017. Analisa Laporan Keuangan. Cetakan 1. Malang: UBMedia.

Kasmir. 2015. Analisis Laporan Keuangan. Jakarta: Rajawali Pers.

Munawir, S. 2004. Analisa Laporan Keuangan. Edisi 4 Cetakan 13. Yogyakarta: Liberty Yogyakarta.

Nuryaman, dan Veronica Christina. 2015. Metode Penelitian Akuntansi dan Bisnis. Bandung: Ghalia Indonesia.

Prawoto, Agus. 2005. Penilaian Usaha. Edisi 2004/2005. Yogyakarta: BPFEYogyakarta.

Prihadi, Toto. 2012. Memahami Laporan Keuangan sesuai IFRS dan PSAK. Cetakan 1. Jakarta: PPM.

-------. 2013. Analisis Laporan Keuangan Lanjutan (Proyeksi dan Valuasi). Cetakan 13. Jakarta: PPM.

Sanusi, Anwar. 2011. Metode Penelitian Bisnis. Jakarta: Salemba Empat.

Silaen, Sofar dan Widoyono. 2013. Metodologi Penelitian Sosial untuk Penulisan Skripsi dan Tesis. Jakarta: In Media.

Silaen, Sofar. 2018. Metodologi Penelitian Sosial untuk Penulisan Skripsi dan Tesis. Edisi Revisi. Jakarta: In Media.

Sudaryono. 2018. Metodologi Penelitian. Edisi 1 Cetakan 2. Depok: Rajawali Pers.
Sugiono, Arief dan Edi Untung. 2016. Panduan Praktis Dasar Analisa Laporan Keuangan. Jakarta: Grasindo.

Sugiyono. 2017. Metode Penelitian Kuantitatif, Kualitatif, dan R\&D. Bandung: Alfabeta. 